Revista Eletrônica Geografar, Curitiba, v. 2, Resumos do VI Seminário Interno de Pós-Graduação em Geografia, p. 73-73. Junho/2007

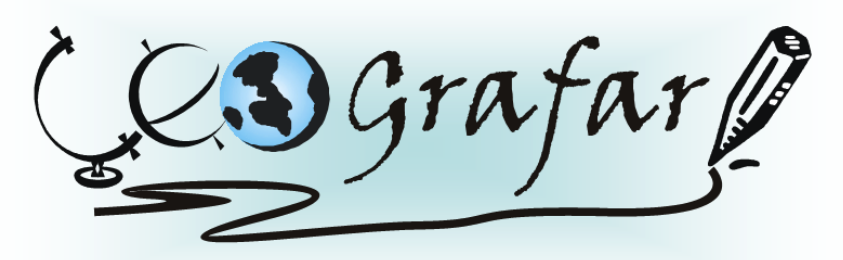

Revista Eletrônica do Programa de Pós-Graduação em Geografia - UFPR

\title{
OS IMPACTOS DAS POLÍTICAS DE DESENOLVIMENTO REGIONAL EM GOIÁS: ANÁLISE DO GOVERNO FHC E LULA NO PERÍODO DE 1999 A 2006
}

\author{
WEDER DAVID DE FREITAS ${ }^{1}$
}

A presente pesquisa buscará compreender as transformações ocorridas no espaço goiano, partindo da análise das políticas de desenvolvimento regional dos governos de Fernando Henrique Cardoso (1999-2002) e Luiz Inácio Lula da Silva (2003-2006). Sabendo da grande heterogeneidade que é o território brasileiro: ambiental, geológica, cultural, etc., mas principalmente econômica o Estado buscou e busca diversas alternativas para que a disparidade regional, ao menos em teoria, seja minimizada. Os motivos para a atuação do Estado são diversos: incorporar as áreas economicamente mais distantes ao capital nacional, fortalecer o pacto federativo, intervir administrativamente etc. (Oliveira, 1993), por isso há a necessidade de uma intervenção territorial, visto que o mercado por si só não consegue diminuir ou acabar com tais diferenças econômicas. Para saber de forma ligeiramente concreta qual o grau de intervenção dessa instituição no espaço goiano, nos interessa analisar as duas políticas de desenvolvimento regional que tem em suas matrizes teóricas modelos diferentes. A Primeira com o governo do presidente Fernando Henrique Cardoso e os Eixos Nacionais de Integração e Desenvolvimento (ENID) e a do governo de Luiz Inácio Lula da Silva com a Política Nacional de Desenvolvimento Regional, a velha/nova política das Superintendências de Desenvolvimento das regiões, ou seja, o objetivo da pesquisa perpassa pela análise significativa dessas políticas de desenvolvimento regional. Nesse sentido pergunta-se: Qual a contribuição dessas políticas para a transformação espacial do Estado de Goiás nos últimos anos? Em que elas auxiliaram a modernização do território goiano? Qual a intervenção de um Estado de matriz neoliberal como o brasileiro no território goiano? Existe uma contradição nesse processo? São questões que nos instiga a procurar respostas. Sendo possível respondê-las com uma pesquisa profunda de base teórica e empírica.

Palavras Chaves: desenvolvimento regional - espaço goiano - eixos nacionais de desenvolvimento e integração.

${ }^{1}$ Mestrando em Geografia - UFPR - email: wederfreitas@yahoo.com.br Orientador: LUÍS LOPES DINIZ FILHO 